\title{
I I
}

\section{ЕКОНОМІКА ПРИРОДОКОРИСТУВАННЯ ТА ЕКОЛОГІЗАЦІЯ НАВКОЛИШНЬОГО СЕРЕДОВИЩА}

УДК 632.93:633.71

JEL Classification: Q 16
DOI: 10.37332/2309-1533.2019.7-8.15

Бялковська Г.Д., канд. екон. наук, завідувач науково-технологічного відділу тютюнництва, Пащенко В.І., науковий співробітник, науково-технологічного відділу тютюнництва, Тернопільська державна сільськогосподарська дослідна станція ІКСГП НАAН

\section{НОВІ ЕЛЕМЕНТИ ТЕХНОЛОГІЇ ВИРОЩУВАННЯ I ЗАХИСТУ ТЮТЮНУ ВІД ШКІДЛИВИХ ОРГАНІЗМІВ ТА ІІІ ЕКОНОМІЧНЕ ОБҐРУНТУВАННЯ}

Bialkovska H.D., cand.sc.(econ.), head of science and technology department of tobacco,

Pashchenko V.I., researcher of science and technology department of tobacco, Ternopil State Agricultural Experimental Station of the IFRAP of NAAS

\section{NEW ELEMENTS OF TECHNOLOGY FOR THE GROWING AND PROTECTION OF TOBACCO FROM HARMFUL ORGANISMS AND ITS ECONOMIC SUBSTANTIATION}

Постановка проблеми. Функціонування аграрного сектору економіки в умовах ринку потребує нових підходів до наукового забезпечення сільськогосподарського виробництва. Стають актуальними прикладні дослідження в галузі тютюнництва: оптимізація існуючих агротехнічних прийомів, використання нових стимуляторів росту та інсектицидів. Питання внесення стимуляторів росту під тютюн вивчено недостатньо, що зумовлює необхідність дослідження впливу, дозволених до застосування на культурах родини пасльонових, стимуляторів росту, які б забезпечували одержання стабільних урожаїв тютюнової сировини.

Основним завданням тютюнової галузі є забезпечення високої врожайності тютюну та якості кінцевого продукту. Важливим резервом підвищення врожайності тютюну та покращення якості тютюнової сировини є використання регуляторів росту рослин. Вони все більше стають невід'ємними елементами технології вирощування різних культур. Особливого значення регулятори росту набувають у випадках, коли технологія вирощування не відповідає генетичним можливостям сорту щодо забезпечення достатнього ступеня надійності та захищеності генотипу від несприятливого впливу біотичних та абіотичних факторів середовища [1;2].

Аналіз останніх досліджень і публікацій. Наукові дослідження технології вирощування та захисту тютюну від шкідливих організмів в Україні проводяться вченими науково-технологічного відділу тютюнництва Тернопільської державної сільськогосподарської дослідної станції ІКСГП НААН (ТДСГДС): Бялковською Г. Д., Пащенком В. І., Гаврилюком О. С. [1; 3]. 
В 2011-2013 роках науково-технологічним відділом тютюнництва розроблена інноваційна ресурсоощадна технологія вирощування тютюну сортів української селекції та проведено її економічне обґрунтування із використанням біопрепарату Пентафаг-С та гербіциду Пантера $4 \%$ к. е. [4]. Проводилась робота з удосконалення розробленої технології шляхом застосування стимуляторів росту та інсектицидів нового покоління (дешевших, екологічно безпечніших), а саме: стимуляторів росту Спідфол Аміно Марин, Мегафол та МаксіКроп Старт, протизлакових гербіцидів Фюзілад Форте та Тарга Супер інсектицидів Фастак, Конфідор максі у 2014-2015 роках та інсектициду Командор і стимулятора росту Вимпел протягом 2016-2018 років [5; 6; 7; 8].

Застосування біостимуляторів росту дає змогу якомога повніше реалізувати потенційні можливості рослин, закладені в геномі природою та селекцією, регулювати строки дозрівання, покращувати якість і збільшувати продуктивність тютюну. Вони впливають на систему гормональної регуляції, яка визначає характер таких найважливіших фрізіологічних процесів, як ріст, утворення нових органів, перехід рослин до цвітіння, старіння, стану спокою або вихід з нього.

Позитивно оцінюючи результати останніх досліджень і публікацій, постійне оновлення стимуляторів росту та інсектицидів на ринку, встановлено доцільність продовження вивчення поставленої проблеми, зокрема проведення моніторингу та підбору пестицидів нового покоління для подальшого збільшення врожайності, покращення якості та збільшення рентабельності виробництва тютюнової сировини та її конкурентоспроможності на ринку України.

Постановка завдання. Метою дослідження $€$ вивчення впливу екологічно безпечних пестицидів на ріст та розвиток рослин тютюну та проведення економічної оцінки його результатів.

Об'єктом дослідження є застосування нових хімічних препаратів - стимулятора росту Вимпел та інсектициду Командор на тютюнових площах сорту Берлей 46.

Основним завданням досліджень було вивчення нових елементів технології вирощування і захисту тютюну від хвороб і шкідників, які дозволяють збільшити рентабельність виробництва тютюнової сировини сортів української селекції в агрокліматичних умовах Придністров'я України.

Матеріалом дослідження при економічній оцінці технології, що включає операції із застосуванням нових піддослідних пестицидів, слугували технологічні карти на вирощування тютюну, розроблені науковими співробітниками науково-технологічного відділу тютюнництва ТДСГДС.

Виклад основного матеріалу дослідження. Новими елементами технології вирощування і захисту тютюну від шкідливих організмів $є$ застосування стимулятора росту Вимпел та інсектициду Командор. Ефективність застосування даних пестицидів у посадках тютюну вивчалася протягом 2016-2018 років в полі № 1 наукової сівозміни науково-технологічного відділу тютюнництва [8].

За результатами наукових досліджень 2016-2018 років вченими науково-технологічного відділу тютюнництва встановлено позитивний вплив стимулятора росту рослин Вимпел на динаміку росту і якісні параметри тютюнової сировини сорту Берлей 46 (табл. 1). Одержані дані біометричних показників і економічно-технологічні розрахунки дозволили визначити оптимальну дозу внесення досліджуваного препарату - 0,8 л/га. Згідно наукової методології перше обприскування вищевказаним препаратом проведено через 10 днів після висаджування розсади у полі, застосовуючи норму внесення 0,3 л/га, через 25 днів після садіння провели повторне внесення стимулятора росту 3 нормою внесення 0,5 л/га.

Вплив стимулятора росту Вимпел на врожай та якість тютюну сорту Берлей 46 (середнє за 2016-2018 рр.)

\begin{tabular}{|c|c|c|c|c|c|c|}
\hline \multirow{2}{*}{ № $3 / \Pi$} & \multirow{2}{*}{ Варіанти досліду } & \multirow{2}{*}{$\begin{array}{c}\text { Висота рослин в } \\
\text { кінці вегетації, см }\end{array}$} & \multicolumn{2}{|c|}{$\begin{array}{c}\text { Площа листової } \\
\text { пластинки, см² }\end{array}$} & \multirow{2}{*}{$\begin{array}{l}\text { Урожай- } \\
\text { ність, ц/га }\end{array}$} & \multirow{2}{*}{$\begin{array}{c}\text { Вихід } \\
(I+I I), \\
\text { товарних } \\
\text { сортів, \% }\end{array}$} \\
\hline & & & довжина & ширина & & \\
\hline 1. & Контроль (без обприскування) & 131 & 42 & 28 & 25,5 & 84 \\
\hline 2. & Мегафол“-еталон & 148 & 45 & 31 & 29,8 & 92 \\
\hline 3. & Вимпел ${ }^{* *}$ & 152 & 50 & 31 & 30,4 & 93 \\
\hline
\end{tabular}
2016-2018 pp.

В результаті проведення біометричних вимірювань встановлено висоту рослин тютюну 152 см, що на 21 см вище у порівнянні з контрольним варіантом, значно зросла площа листової пластини: на 8 см збільшились довжина і на 3 см - ширина. Стимулятор росту Вимпел сприяв підвищенню врожайності тютюну сорту Берлей 46 прибавка урожаю склала 4,9 ц/га порівняно 3 контрольним варіантом та 0,6 ц/га відносно еталону (в нашому досліді ним слугував препарат Мегафол). 
Покращилася якість тютюнової сировини - вихід вищих товарних сортів становив 93\%, що на 9\% більше, ніж на контролі (табл. 2).

Таблиця 2

Вплив стимуляторів росту на урожайність тютюну в 2016-2018 рр.

\begin{tabular}{|c|l|c|c|c|c|c|}
\hline \multirow{2}{*}{$\begin{array}{c}\text { № } \\
\text { 3/п }\end{array}$} & \multicolumn{2}{|c|}{ Варіант досліду } & \multicolumn{5}{c|}{ Урожайність, сухе листя, ц/га } \\
\cline { 3 - 7 } & & 2016 р. & 2017 р. & 2018 р. & середня & 土 до контролю \\
\hline 1. & Контроль (без обприскування) & 15,3 & 30,2 & 30,9 & 25,5 & 0 \\
\hline 2. & Мегафол-еталон & 16,7 & 36,5 & 36,3 & 29,8 & $+4,3$ \\
\hline 3. & Вимпел & 17,2 & 37,3 & 36,7 & 30,4 & $+4,9$ \\
\hline
\end{tabular}
2016-2018 pp.

За останні роки дослідження показали, що головним показником ефективності впливу інсектицидів на сисних комах (в досліді - тютюновий трипс) $€$ інтенсивність ураження рослин бронзовістю томатів (Tomato spotted wilt virus) в системній і листовій фрормі ураження. За умови обробки розсади інсектицидами в парнику за 3 дні до висаджування рослин у поле і обприскуванні в полі через 7 днів після посадки забезпечується надійний захист від ураження тютюну бронзовістю томатів.

В результаті застосування інсектициду Командор отримано кращі захисні властивості від ураження бронзовістю томатів, що дозволить збільшити урожайність на 4,8 ц/га та знизити ураженість бронзовістю томатів на $54,3 \%$ в порівнянні з дослідною ділянкою, де обробка інсектицидами не проводилася (табл. 3).

Таблиця 3

Технічна та економічна ефективність застосування хімічних обробок тютюну для захисту від ураження бронзовістю томатів сорту Берлей 46 (середнє за 2016-2018 рр.)

\begin{tabular}{|c|c|c|c|c|c|}
\hline \multirow{2}{*}{$\begin{array}{l}\text { № } \\
3 / \text { ח }\end{array}$} & \multirow{2}{*}{ Варіант досліду } & \multicolumn{2}{|c|}{ Ураженість хворобою, \% } & \multirow{2}{*}{$\begin{array}{c}\text { Урожайність, } \\
\text { сухе листя, ц/га }\end{array}$} & \multirow{2}{*}{$\begin{array}{c}\text { Прибавка } \\
\text { урожаю }\end{array}$} \\
\hline & & фрактична & зниження & & \\
\hline 1. & Без обробки - контроль & 3,5 & - & 24,7 & - \\
\hline 2. & Бі-58 (новий) - еталон * & 1,9 & 45,7 & 28,8 & 4,1 \\
\hline 3. & Командор ** & 1,6 & 54,3 & 29,5 & 4,8 \\
\hline
\end{tabular}

Науковцями відділу щорічно оцінюється фітосанітарна ситуація тютюнового агроценозу та складається прогноз фітосанітарного стану агроценозів України з урахуванням щорічних змін в популяціях шкідливих організмів [9]. Одержані результати досліджень дозволили внести нові елементи в удосконалену екологічно безпечну ресурсоощадну технологію захисту тютюну від основних хвороб та шкідників:

1) внесення стимулятора росту Вимпел в дозі 0,3 л/га через 10 днів після садіння тютюну в полі та повторне внесення стимулятора росту Вимпел в дозі 0,5 л/га через 25 днів після висаджування у відкритий ґрунт;

2) обприскування тютюнових плантацій після завершення посадки через $\quad$ 7-10 днів інсектицидом Командор - 0,2 л/га;

На основі типових технологічних карт, що розроблені науковцями-економістами науковотехнологічного відділу тютюнництва, визначено нормативну виробничу собівартість тютюнової сировини на 2018 рік при урожайності 20 ц/га, із урахуванням рівня мінімальної заробітної плати 3723 грн та цін на товарно-матеріальні цінності, що склалися в регіоні в поточному році. Розраховано загальну суму витрат виробництва у грошовому виразі в розрахунку на 1 гектар площі посадки та одиницю продукції (табл. 4).

У 2018 році нормативні грошові витрати на 1 гектар тютюну становлять 111264 грн (при умові, що садіння тютюну і нанизування листя проводили вручну), а собівартість 1 ц сухого листя тютюну дорівнює 5563 грн. 3 підвищенням урожайності тютюну собівартість знижуватиметься. В структурі витрат на виробництво тютюну найбільшу питому вагу займають витрати на заробітну плату 81227 грн або 73,0\% і нарахування на фонд заробітної плати - 15839 грн або 14,2\% і тільки 12,8\% склали матеріальні витрати. Найтрудоємнішим процесом при виробництві тютюнової сировини $є$ 
післязбиральний обробіток тютюну: в структурі витрат відповідно на нього припадає 48,2\% всіх витрат.

\section{Структура нормативної виробничої собівартості тютюнової сировини у 2018 році (загальноприйнята технологія, урожайність 20 ц/га)}

\begin{tabular}{|c|c|c|c|c|c|c|c|}
\hline \multirow[b]{2}{*}{ Технологічний процес } & \multicolumn{3}{|c|}{$\begin{array}{c}\text { Витрати на заробітну плату та нарахування } \\
\text { на фонд зарплати, грн/га }\end{array}$} & \multirow{2}{*}{$\begin{array}{c}\text { Матері- } \\
\text { ально- } \\
\text { грошові } \\
\text { витрати, } \\
\text { грн/га }\end{array}$} & \multicolumn{3}{|c|}{ Грошові витрати, всього, грн } \\
\hline & $\begin{array}{l}\text { заробітна } \\
\text { плата }\end{array}$ & $\begin{array}{c}\text { нарахування } \\
19,5 \%\end{array}$ & всього & & на 1 га & $\begin{array}{l}\text { на } 1 \text { ц } \\
\text { сухого } \\
\text { листя }\end{array}$ & $\begin{array}{c}\text { \% в } \\
\text { струк- } \\
\text { турі } \\
\end{array}$ \\
\hline Вирощування розсади & 8610 & 1679 & 10289 & 2490 & 12779 & 639 & 11,5 \\
\hline $\begin{array}{l}\text { Обробіток Ґрунту, } \\
\text { внесення добрив }\end{array}$ & 200 & 39 & 239 & 1582 & 1821 & 91 & 1,6 \\
\hline Садіння розсади & 5688 & 1109 & 6797 & 3444 & 10241 & 512 & 9,2 \\
\hline Польовий догляд & 2298 & 448 & 2746 & 1127 & 3873 & 194 & 3,5 \\
\hline Збирання тютюну & 15847 & 3090 & 18937 & 4195 & 23132 & 1157 & 20,8 \\
\hline $\begin{array}{l}\text { Післязбиральний } \\
\text { обробіток }\end{array}$ & 44126 & 8605 & 52731 & 952 & 53683 & 2684 & 48,2 \\
\hline Первинна обробка & 4458 & 869 & 5327 & 408 & 5735 & 287 & 5,2 \\
\hline Всього: & 81227 & 15839 & 97066 & 14198 & 111264 & 5563 & 100 \\
\hline
\end{tabular}

Джерело: дані заключних наукових звітів науково-технологічного відділу тютюнництва ТДСГДС за 2016-2018 pp.

У 2018 році витрати на вирощування тютюну зросли на 12,6\%, в порівнянні 32017 роком, а закупівельні ціни на тютюн (сухий лист) залишились на рівні минулого року і $є$ такими (без податку на додану вартість): I та II товарні сорти - 6250 грн/ц, III - 5000 грн/ц, IV сорт - 4000 грн/ц.

3 метою подальшого економічного обґрунтування елементів технології вирощування і захисту тютюну від шкідливих організмів проведено вартісну оцінку нових пестицидів, що вивчались в наукових дослідженнях 2018 року (табл. 5).

\section{Оцінка технології із застосуванням пестицидів у 2018 р.}

Таблиця 5

\begin{tabular}{|c|c|c|c|c|}
\hline $\begin{array}{l}\text { № } \\
\text { 3/ח }\end{array}$ & $\begin{array}{c}\text { Назва досліджуваних хімічних } \\
\text { препаратів, норма внесення }\end{array}$ & $\begin{array}{c}\text { Вартість досліджуваних } \\
\text { хімічних препаратів, грн/га }\end{array}$ & $\begin{array}{c}\text { Урожайність } \\
\text { (сухе листя), ц/га }\end{array}$ & $\begin{array}{c} \pm \text { до } \\
\text { контролю, } \\
\text { ц/га }\end{array}$ \\
\hline \multicolumn{5}{|c|}{ Технологія із застосуванням стимуляторів росту } \\
\hline 1. & Без обприскування (контроль) & - & 30,9 & - \\
\hline 3. & Мегафол 5 л/га (еталон) & 2025 & 36,3 & 5,4 \\
\hline 2. & Вимпел 0,8 л/га & 250 & 36,7 & 5,8 \\
\hline \multicolumn{5}{|c|}{ Технологія із застосуванням інсектицидів } \\
\hline 1. & Без обприскування (контроль) & - & 29,3 & - \\
\hline 2. & Бі-58 (новий) - 1 л/га (еталон) & 380 & 35,6 & 6,3 \\
\hline 3. & Командор 0,2 л/га & 106 & 36,2 & 6,9 \\
\hline
\end{tabular}
2016-2018 pp.

Як видно із наведених даних в табл. 5, серед досліджуваних стимуляторів росту найефективнішим є Вимпел: його вартість з розрахунку на 1 гектар дорівнює 250 грн, урожайність 36,7 ц/га, що на 0,4 ц/га більше, ніж результат, отриманий в дослідах з препаратом Мегафол, де врожайність становила 36,3 ц/га.

Проведено економічне обґрунтування ефективності застосування нових стимуляторів росту в наукових дослідженнях 2016-2018 років (табл. 6).

Розрахунки показують, що у 2016 році найвищу рентабельність - 49,8\%, отримано в результаті застосування стимулятора росту Вимпел, при цьому собівартість 1 ц сухого тютюну склала 2670 грн і $€$ найнижчою, а прибуток з 1 гектара дорівнював 22876 грн.

У 2017 році найвищу рентабельність - 41,5\%, отримано також в результаті застосування стимулятора росту Вимпел, при цьому собівартість 1 ц сухого тютюну склала 4240 грн, а прибуток з 1 гектара становив 65648 грн. 


\section{Економічна ефективність досліджуваних стимуляторів росту в технології вирощування тютюну за 2016-2018 рр.}

\begin{tabular}{|c|c|c|c|c|c|c|c|c|}
\hline $\begin{array}{l}\text { № } \\
\Pi / \Pi\end{array}$ & Назва препаратів & $\begin{array}{c}\text { Урожай- } \\
\text { ність, } \\
\text { ц/га }\end{array}$ & $\begin{array}{c}\text { Собі- } \\
\text { вартість } \\
1 \text { ц, грн }\end{array}$ & $\begin{array}{c}\text { Всього } \\
\text { витрат, } \\
\text { грн/га }\end{array}$ & $\begin{array}{l}\text { Виручка } \\
\text { грн/га* }\end{array}$ & $\begin{array}{c}\text { Прибуто } \\
\text { к грн/га }\end{array}$ & $\begin{array}{c}\text { Рентабель- } \\
\text { ність, \% }\end{array}$ & $\begin{array}{c} \pm \text { до } \\
\text { конт- } \\
\text { ролю } \\
\% \\
\end{array}$ \\
\hline \multicolumn{9}{|c|}{2016 рік } \\
\hline 1. & $\begin{array}{l}\text { Контроль - без } \\
\text { обприскування }\end{array}$ & 15,3 & 2860 & 43758 & 61200 & 17442 & 39,9 & - \\
\hline 2. & Мегафол & 16,7 & 2750 & 45925 & 66800 & 20875 & 45,4 & $+5,5$ \\
\hline 3. & Вимпел & 17,2 & 2670 & 45924 & 68800 & 22876 & 49,8 & $+9,9$ \\
\hline \multicolumn{9}{|c|}{2017 рік } \\
\hline 1. & $\begin{array}{l}\text { Контроль - без } \\
\text { обприскування }\end{array}$ & 30,2 & 4440 & 134088 & 181200 & 47112 & 35,1 & - \\
\hline 2. & Мегафол & 36,5 & 4290 & 156585 & 219000 & 62415 & 39,9 & $+4,8$ \\
\hline 3. & Вимпел & 37,3 & 4240 & 158152 & 223800 & 65648 & 41,5 & $+6,4$ \\
\hline \multicolumn{9}{|c|}{2018 рік } \\
\hline 1. & $\begin{array}{l}\text { Контроль - без } \\
\text { обприскування }\end{array}$ & 30,9 & 5000 & 154500 & 185400 & 30900 & 20,0 & - \\
\hline 2. & Мегафол & 36,3 & 4830 & 175329 & 217800 & 42471 & 24,0 & $+4,0$ \\
\hline 3. & Вимпел & 36,7 & 4810 & 176527 & 220200 & 43673 & 24,7 & $+4,7$ \\
\hline
\end{tabular}

-6000 грн/ц

Джерело: дані заключних наукових звітів науково-технологічного відділу тютюнництва ТДСГДС за 2016-2018 pp.

Результат наукових досліджень 2018 року остаточно підтвердив найвищу ефективність використання на тютюнових площах стимулятора росту Вимпел, рівень рентабельності становив 24,7\%, при цьому собівартість 1 ц сухого тютюну склала 4810 грн і $€$ нижчою, ніж в досліді, де застосовували Мегафол, а прибуток з 1 гектара становив 43673 грн.

В процесі науково-дослідних робіт обґрунтовано економічну ефективність застосування нових інсектицидів в дослідженнях 2016-2018 років (табл. 7).

\section{Економічна ефективність досліджуваних інсектицидів в технології вирощування тютюну за 2016-2018 рр.}

Таблиця 7

\begin{tabular}{|c|c|c|c|c|c|c|c|c|}
\hline $\begin{array}{l}\text { № } \\
\text { 3/ח }\end{array}$ & Назва препаратів & $\begin{array}{c}\text { Урожай- } \\
\text { ність, } \\
\text { ц/га }\end{array}$ & $\begin{array}{c}\text { Собі- } \\
\text { вартість } \\
1 \text { ц, грн }\end{array}$ & $\begin{array}{c}\text { Всього } \\
\text { витрат, } \\
\text { грн/га }\end{array}$ & $\begin{array}{l}\text { Виручка, } \\
\text { грн/га* }\end{array}$ & $\begin{array}{l}\text { Прибуток, } \\
\text { грн/га }\end{array}$ & $\begin{array}{l}\text { Рента- } \\
\text { бельні- } \\
\text { сть, \% }\end{array}$ & $\begin{array}{c} \pm д о ~ \\
\text { конт- } \\
\text { ролю, } \\
\%\end{array}$ \\
\hline 1 & 2 & 3 & 4 & 5 & 6 & 7 & 8 & 9 \\
\hline \multicolumn{9}{|c|}{2016 рік } \\
\hline 1. & $\begin{array}{l}\text { Контроль - без } \\
\text { обприскування }\end{array}$ & 14,4 & 3030 & 43632 & 57600 & 13968 & 32,0 & - \\
\hline 2. & $\begin{array}{l}\text { Бі-58 (новий) - } \\
\text { еталон }\end{array}$ & 15,4 & 2910 & 44814 & 61600 & 16786 & 37,4 & $+5,4$ \\
\hline 3. & Командор & 16,1 & 2870 & 45724 & 64400 & 18676 & 40,8 & $+8,8$ \\
\hline \multicolumn{9}{|c|}{2017 рік } \\
\hline 1. & $\begin{array}{l}\text { Контроль - без } \\
\text { обприскування }\end{array}$ & 30,4 & 4438 & 134910 & 182400 & 47490 & 35,2 & - \\
\hline 2. & $\begin{array}{l}\text { Бі-58(новий) - } \\
\text { еталон }\end{array}$ & 35,4 & 4343 & 153742 & 212400 & 58658 & 38,1 & $+2,9$ \\
\hline 3. & Командор & 36,3 & 4287 & 155618 & 217800 & 62182 & 40,0 & $+4,8$ \\
\hline
\end{tabular}




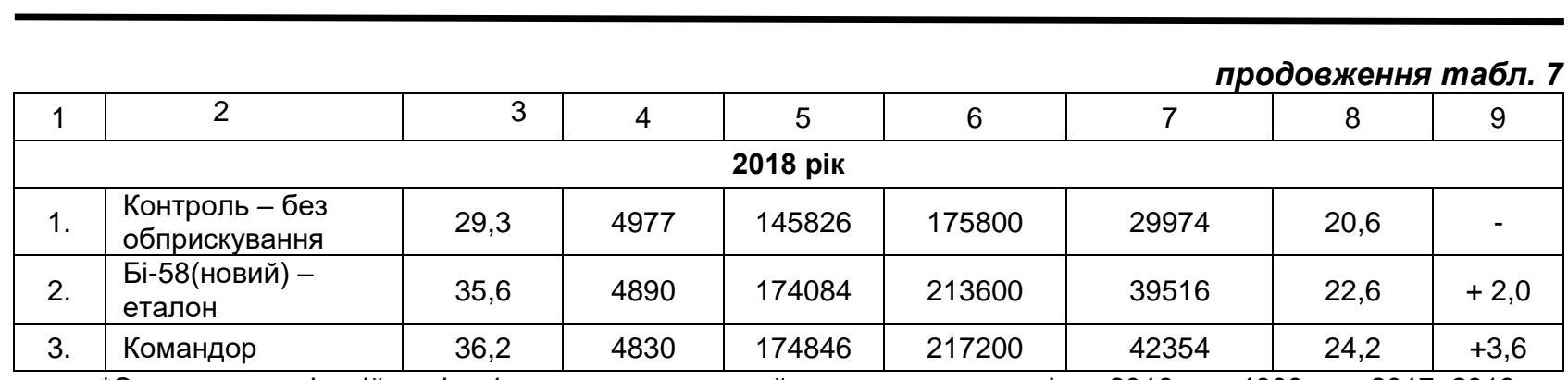

*Середньореалізаційна ціна 1 ц сухого листя, прийнята для розрахунків, у 2016 р. - 4000 грн, 2017-2018 рр. -6000 грн/ц

Джерело: дані заключних наукових звітів науково-технологічного відділу тютюнництва ТДСГДС за 2016-2018 pp.

Серед досліджуваних інсектицидів у 2016 році найкращі показники ефективності виявлено при внесенні Командору: прибуток склав 18676 грн/га, а рівень рентабельності - 40,8\%.

У 2017 році кращий економічний результат отримано при внесенні Командору: прибуток склав 62182 грн/га, а рівень рентабельності - 40,0\%.

Економічний аналіз досліджуваних інсектицидів в 2018 році показав найкращу ефективність дії інсектициду Командор: прибуток склав 42354 грн/га, а рівень рентабельності - 24,2\%.

Отже, за результатами використання нових хімічних препаратів в наукових дослідженнях 20162018 років найкращі показники економічної ефективності виявлено при застосуванні стимулятора росту Вимпел та інсектициду Командор.

Висновки 3 проведеного дослідження. Таким чином, за результатами проведеного дослідження:

1. Розроблено рекомендації із використанням стимулятора росту Вимпел та інсектициду Командор як ефективних препаратів підвищення врожайності та якості тютюнової сировини нового сорту тютюну української селекції Берлей 46 в умовах Придністров'я України. Їх застосування значно підвищує рівень рентабельності процесу вирощування тютюнової сировини за рахунок підвищення стійкості рослин до несприятливих фракторів навколишнього середовища [10].

2. Обґрунтовано нові елементи технології захисту тютюну від шкідливих організмів за умов регулювання їх розвитку і чисельності з впровадженням у виробництво стійких і комплексно стійких сортів тютюну української селекції.

Одержані результати проведеної економічної оцінки застосування нових екологічно безпечних препаратів в технології вирощування тютюну дають підставу зробити наступні висновки:

а) внесення стимулятора росту Вимпел в дозі 0,3 л/га через 10 днів після садіння тютюну в полі та повторне внесення стимулятора росту Вимпел в дозі 0,5 л/га через 25 днів після висаджування у відкритий ґрунт дає можливість отримати додатковий прибуток 12240 грн/га;

б) обприскування тютюнових плантацій після завершення посадки через 7-10 днів інсектицидом Командор (оптимальна доза внесення 0,2 л/га) гарантує отримання додаткового прибутку в сумі 10590 грн/га.

\section{Література}

1. Бялковська Г.Д., Пащенко В.І., Гаврилюк О.С. Інноваційна ресурсоощадна технологія вирощування тютюну сортів української селекції та її економічне обґрунтування. Інноваційна економіка. 2014. № 3(52). С. 142-149.

2. Шпек М. П., Коссак Г. М., Лупак О. М. Вплив біостимуляторів росту рослин на продуктивність Matricaria recutita L. в умовах Прикарпаття. Лікарські рослини: традиції та перспективи досліджень: матеріали III Міжнарод. наук. конф., присвяченій 100-річчю Досл. станції лікар. рослин, ДСлР ІАП НААН. Київ : ТОВ «ДІА», 2016. С. 147-150.

3. Бялковська Г. Д., Пащенко В. І. Удосконалена екологічно безпечна ресурсоощадна технологія вирощування високоякісного тютюну та її економічне обґрунтування. Сталий розвиток економіки. 2017. № 3(36). С. 137-144.

4. Інноваційні ресурсоощадні технології вирощування нових сортів високоякісного тютюну в розсадний і польовий періоди для Придністров'я України: звіт по НДР (остаточний 2011-2013 рр.): № ДР 0111 U003757 / ТДСГДС ІКСГП ННАН. Тернопіль, 2013. 40 с.

5. Удосконалити ресурсоощадні технології виробництва тютюну: звіт по НДР (остаточний 20142015 рр.): № ДР 0114 О000292 / ТДСГДС ІКСГП ННАН. Тернопіль, 2015. 46 с.

6. Пащенко В.І. Застосування інсектицидів Фастак та Конфідор Максі в удосконаленій екологічно безпечній ресурсоощадній технології вирощування тютюну. Актуальні питання сучасних технологій вирощування сільськогосподарських культур в умовах змін клімату : Всеукр. наук.-практ. конф. (Кам'янець-Подільський, 15-16 черв. 2017 р.). Тернопіль : Крок, 2017. С. 150-153. 
7. Пащенко В., Гаврилюк О. Застосування проти злакових гербіцидів Фюзілад Форте та Тарга Супер в удосконаленій екологічно безпечній ресурсоощадній технології вирощування тютюну. Аграрна наука та освіта в умовах євроінтеграції: Міжнар. наук.-практ. конфо. (м. Кам'янецьПодільський, 22 берез. 2018 р.). Тернопіль : Крок, 2018. С. 125-127.

8. Розробити елементи технології вирощування і захисту тютюну від шкідливих організмів: звіт по НДР (остаточний 2016-2018рр.): № ДР 0116U003444 / ТДСГДС ІКСГП НААН. Тернопіль, 2018. 56 с.

9. Пащенко В.І. Хвороби та шкідники тютюну. Прогноз фрітосанітарного стану агроценозів України та рекомендації щодо захисту рослин у 2018 р. Київ, 2018. С. 109-111.

10. Бялковська Г. Д., Пащенко В.І., Гаврилюк О. С., Вельган $€$. Л. Науково-практичні рекомендації екологічно безпечної технології вирощування і захисту тютюну від хвороб та шкідників 3 елементами використання найефективніших стимуляторів росту та інсектицидів / за ред. канд. екон. наук Бялковської Г. Д. Тернопіль : ТДСГДС ІКСГП НААН, 2018. 17 с.

\section{References}

1. Bialkovska, H.D., Paschenko, V.I. and Havriliuk, O.S. (2014), "Innovative saving technology of grooving of tobacco of sorts of Ukrainian selection and it economic ground", Innovative economy, no. 3 (52), pp. $142-149$.

2. Shpek, M.P., Kossak, G.M. and Lupak, O.M. (2016), "The influence of growth biostimulants on the productivity of Matricaria recutita L. in the conditions of Precarpathians", Likarski roslyny: tradytsii ta perspektyvy doslidzhen : materialy III Mizhnarod. nauk. konf., prysviachenii 100-richchiu Dosl. stantsii likar. roslyn [Medical plants: traditions and prospects of researches: Proceedings of III Intern. sciences. conf., sanctified to the 100 year of Experim. the stations are a medical plants], ESMP IAE NAAS, LTD "DIA", Kyiv, Ukraine, pp. 147-150.

3. Bialkovska, H.D. and Pashchenko, V.I. (2017), "Improved saving resources technology of growing of high quality tobacco and its economic grounding", Stalyi rozvytok ekonomiky, no. 3 (36), pp. 137-144.

4. TDSHDS IKSHP NAAN (2013), Innovatsiini resursooshchadni tekhnolohii vyroshchuvannia novykh sortiv vysokoiakisnoho tiutiunu $v$ rozsadnyi i polovyi periody dlia Prydnistrov'ia Ukrainy: zvit po NDR (ostatochnyi 2011-2013 rr.): № DR 0111 U003757 [Innovative resource-saving technologies of growing of new varieties of high-quality tobacco are in seedling and field periods for Pridnistrovia of Ukraine: report is about SRW (final after 2011-2013): № SR 0111U003757], Ternopil, Ukraine, 40 p.

5. TDSHDS IKSHP NAAN (2015), Udoskonalyty resursooshchadni tekhnolohii vyrobnytstva tiutiunu: zvit po NDR (ostatochnyi 2014-2015 rr.): № DR 0114U000292 [Improve the resource-saving technologies of tobacco production: report is about SRW (final after 2014-2015): № SR 0114U000292], Ternopil, Ukraine, 46 p.

6. Pashchenko, V.I. (2017), "The use of the insecticides Fastac and Confidor Maxi in advanced ecofriendly tobacco-friendly resource-saving technology of grooving of tobacco", Aktualni pytannia suchasnykh tekhnolohii vyroshchuvannia silskohospodarskykh kultur v umovakh zmin klimatu : Vseukr. nauk. -prakt. konf. [Topical issues of modern technologies of cultivation of crops in the conditions of climate change: All-Ukr. research practice conf.], (Kamianets-Podilskyi, 15-16 June 2017), Krok, Ternopil, Ukraine, pp. 150-153.

7. Pashchenko, V. and Havriliuk, O. (2018), "Application against Cereal Herbicides Fusilad Forte and Targa Super in advanced eco-friendly tobacco-friendly resource-saving technology", Ahrarna nauka ta osvita $v$ umovakh yevrointehratsii : Mizhnar. nauk.-prakt. konf. [Agrarian science and education in the context of European integration : Intern. sciences.-pract. conf.], (Kamianets-Podilskyi, 22 March 2018), Krok, Ternopil, Ukraine, pp. 125-127.

8. TDSHDS IKSHP NAAN (2018), Rozrobyty elementy tekhnolohii vyroshchuvannia i zakhystu tiutiunu vid shkidlyvykh orhanizmiv: zvit po NDR (ostatochnyi 2016-2018 rr.): № DR 0116 U003444 [Develop elements of technology for growing and protecting tobacco from harmful organisms: report is about SRW (final after 2016-2018): № SR 0116U003444], Ternopil, Ukraine, 56 p.

9. Pashchenko, V.I. (2018), "Diseases and pests of tobacco", Forecast of phytosanitary status of agrocenoses of Ukraine and recommendations for plant protection in 2018 year, Kyiv, Ukraine, pp. 209-211.

10. Bialkovska, H.D., Pashchenko, V.I., Havriliuk, O.S. and Velhan, E.L. (2018), Naukovo-praktychni rekomendatsii ekolohichno bezpechnoi tekhnolohii vyroshchuvannia i zakhystu tiutiunu vid khvorob ta shkidnykiv z elementamy vykorystannia naiefektyvnishykh stymuliatoriv rostu ta insektytsydiv [Scientific and practical recommendations of environmentally friendly technology for growing and protecting tobacco from diseases and pests with elements of using the most effective growth promoters and insecticides],TDSHDS IKSHP NAAN, Ternopil, Ukraine, $17 \mathrm{p}$. 